\title{
Assessment of the Efficacies of Inverted Classroom Approach and Powerpoint Presentation on Students' Achievement and Self-Efficacy in Biology
}

\author{
Chinweuba-eze, V.O. \\ Department of Science Education, Faculty of Education University of Nigeria Nsukka \\ Enugu State, Nigeria
}

\begin{abstract}
In this paper, the effect of inverted classroom approach and PowerPoint presentation on students' achievement and self-efficacy in biology has been discussed. Two research questions and two null hypotheses were formulated to guide the study. A Quasi-experiment of $2 \times 2$ factorial design was adopted to guide the study. 4,408 senior secondary two (SSII) Biology students in Agbani education zone of Enugu state composed the population. The sample size for the study consisted of 150 SSII Biology students. The sample was be drawn using a multistage sampling procedure. the Biology Achievement Test (BAT) and Biology Self-efficacy Scale (BSS) were used as an instrument for data collection. Three experts all from the Department of Science Education, University of Nigeria, Nsukka, validated the instruments. The reliability of BAT was determined using Kuder Richardson (K-R-21) formula which gave a reliability index of 0.79 . The reliability of BSS gave an index of 0.81 using Cronbach alpha formula. Data obtained from the pre-test and post-test were quantitatively analysed. All the research questions were answered using mean and standard deviation while Analysis of Covariance (ANCOVA) was used to test all the hypotheses at 0.05 level of significance. Results from the study revealed that there is a significant effect of approaches on the achievement and self-efficacy of students taught biology using inverted classroom approach, and those taught using the PowerPoint presentation. Based on the findings, it was recommended among others that biology teachers should try to develop and adopt the use of PowerPoint presentation in their instructional delivery as it would enhance the overall achievement and selfefficacy of students in biology.
\end{abstract}

Keywords: Inverted Classroom, PowerPoint Presentation, Achievement, Self-efficacy, Biology

DOI: $10.7176 / \mathrm{JEP} / 12-23-09$

Publication date:August $31^{\text {st }} 2021$

\section{Introduction}

For our daily survival, we all rely on the environment for a variety of critical benefits which includes the air we breathe, the food we eat, and the water we drink. By proper managing of our environment, we can greatly improve our quality of life. Thus, the need for the study of an aspect of natural science termed biology. The origin, anatomy, morphology, physiology, behaviour, and distribution of living organisms could be well understood with the study of biology. According to Buba, Banus and Adamu (2020), biology is a branch of natural science that provides necessary knowledge with which one can use to control or change the environment for the benefit of individual and the entire society at large. This implies that biology is an everyday encounter in our activities and explains the fundamentals of every living organism. Biology is a branch of life science that is concerned with everything involving a life form, no matter how small or large including its structure, behaviour, origin, growth and reproduction (Ihekwoaba, Nzewi, Ifeagwu, Chinweuba-eze \& Nduji, 2020; Nam, 2018). To this end, the importance of biology to human being and his environment cannot be overemphasized.

In Nigeria, the study of biology as a subject kick starts from senior secondary school one (SS1). Though students right from their primary school and junior secondary level were exposed to elementary science and integrated science respectively which have some underlining content of biology. Despite all the early inculcation of biology concept, students' achievement in biology still remains poor (Onu, Anyaegbunam \& Uzoigwe, 2020; Badmus, Bello, Hamzat \& Sulaiman, 2019). Scholars believe that the cause of poor achievement of students in biology could be attributed to lack of qualified teachers and inadequate teaching materials (Agogo \& Naakaa, 2013), bad reading culture (Sotiloye \& Bodunde, 2018), parents illiteracy, bad attitude of students to biology and poor environmental conditions (Akachukwu, Adimonyemma \& Igboabuchi 2018; Ndayambaje, Bikorimana \& Nsanganwimana, 2021), teachers incompetency and use of inappropriate teaching method (Ihekwoaba, 2020; Etobro \& Fabinu, 2017; Albert, Osman \& Yungungu, 2016). This paper would concentrate on teaching method. There are different methods or strategies that are involve in teaching and learning process, some of them includes; direct instruction, flipped classrooms, kinaesthetic learning, inquiry-based learning, expeditionary learning, personalized learning, game-based learning, powerpoint presentation and inverted classroom (Gill, 2021; Zawadi, 2020). The researchers' concentration would be on assessing empirically the area of PowerPoint presentation and inverted classroom. 
Assessment is the process of collecting and analysing data from a variety of sources in order to gain a comprehensive understanding of what students know, comprehend, and can do with their knowledge as a result of their educational experiences. This implies that when assessment is been carried out various methods and tools are used by educators to evaluate, measure, and document students' academic preparedness, learning progress, skill acquisition, and educational requirements. In the same light, Ugwuanyi, Nwankwo and Ugwuoke (2016) opined that assessment is the use of empirical data on students learning to refine programs and improve learning. Therefore, in this paper, the researcher assessed the efficacies of inverted flipped classroom and PowerPoint presentation on students' achievement and self-efficacy in biology.

Inverted classroom is an instructional approach in which students' complete readings at home and work on live problem-solving during class time in order to boost student engagement and learning. The goal of the inverted classroom is a shift from passive learning to accelerated learning in the classroom phase in order to accelerate the acquisition of more demanding competencies such as analysis, synthesis and evaluation (Tolks et al, 2016). Inverted classroom can also be used interchangeably or referred to as blended learning or flipped classroom (Sarah, 2015). Inverted classroom is designed in such a way that the instructors are guided with six (6) structured active learning environment which supports students as they work through them individually and collaboratively (Jakobsen \& Knetemann, 2017). These active learning structures include; define content scope, learning objectives and instructional strategies; students gain familiarity with new material before class (pre class content); activities that motivates students to prepare before class (pre class activities); activities that provides students opportunities to deepen understanding (in class activities); and activities that extends students learning (post class activity). In inverted classroom, students are encouraged to put down questions to ask once they come to class and not just to watch or read the instructional content (Ugwuanyi, Nduji, Elejere \& Omeke, 2020). This is an indication that inverted classroom strategy is student-centered inclusive. Inverted classroom devices include; computers, smart gadgets, internet and many more but are mostly not randomly distributed or purchased by many schools, thus, limited or inadequate in its utilization (Schindler, Burkholder \& Morad, 2017).

Various studies have been carried out in both local and foreign countries on the use of inverted or flipped classroom to enhance students' academic achievement in science education. Some of these studies as revealed by (Ugwuanyi et al, 2020; Zafarghandi, 2018; AlJaser, 2017; Jakobsen \& Knetemann, 2017; Robinson, Roland, Bosse \& Zayas, 2015) indicated that there is an enhancement on achievement scores of flipped classroom students. However, none of these outlined studies was done using students in biology. Thus, the present study tends to determine whether flipped classroom and PowerPoint presentation has effect on students' achievement and self-efficacy in biology.

PowerPoint is one of the information technologies tools that can be deliver lessons in the classroom. Initially, PowerPoint was developed to improve learning by providing the means to develop presentations that are more structured and interesting to audiences (Ugwuanyi, Nwankwo \& Ugwuoke, 2016). PowerPoint presentation can be as simple as consisting only of text on a coloured screen. This doesn't depict the fact that some PowerPoint presentation do not comprise of slides, which may contain text, images, and other media, such as audio clips and movies. Operationally, PowerPoint presentation would be seen as the use of computer software created to create slides with recordings, narrations, transitions and other features in order to aid in teaching and learning of some concepts. Penciner (2013) outlined the steps that must be followed in developing an effective PowerPoint Presentation for teaching and learning. They include; create three documents: speaker notes, a hand out and your slides. This will allow a presenter from putting too much information on a slide.

It is important to note that in PowerPoint presentation, the use of narration and relevant images is paramount which could aid in improving students' achievement. Rankin \& Grudzinki (2011) is of the same view that PowerPoint presentation improve students' attitude toward the instructor and class presentation. Also, previous studies (Adebanjo \& Onabanjo, 2021; Zhang, Yen \& Liu, 2020; Lari, 2014) unveiled that the use of PowerPoint presentation has a significant impact or effect on different psychological construct of students. Though some studies (Marina \& Ridlo, 2020; Mansour, 2019; Anigbo \& Orie, 2018) revealed no significant effect of PowerPoint on students' achievement, interest and retention. Based on the reviewed studies, there is inconsistency in findings and none of the reviewed works compared the efficacies of inverted classroom and PowerPoint presentation on students' achievement and self-efficacy in biology.

Self-efficacy is a subjective assessment of a person's ability to cope with a specific scenario based on their skills and the conditions they confront. Thus, every aspect of human endeavour is influenced by self-efficacy. Self-efficacy determines both the power a person has to handle issues competently and the choices a person is most likely to make by influencing the beliefs a person holds about their power to affect situations (Bandura, 2010). These benefits of self-efficacy are most noticeable and persuasive when it comes to investment habits in health, education, and agriculture (Triantoro, 2013). Studies have shown that in educational sector, self-efficacy of students could be enhanced with the use of powerpoint presentation (Cravero, 2017; Susskind, 2015); and students' expectancy believe (Fernando, Laura \& Amparo, 2017). However, this study would compare between inverted classroom approach and PowerPoint presentation which one improves the self-efficacy of students 
specifically in biology.

The following research questions were posed to guide the study.

1. What are the effect of inverted classroom approach and PowerPoint presentation on students' achievement in Biology?

2. What are the effect of inverted classroom approach and PowerPoint presentation on students' selfefficacy in Biology?

The following null hypotheses, which were tested at 0.05 level of significance, were formulated for the study.

1. There is no significant effect of inverted classroom approach and PowerPoint presentation on students' achievement in biology.

2. There is no significant effect of inverted classroom approach and PowerPoint presentation on students' self-efficacy in biology.

\subsection{Methods}

This study adopted quasi-experiment of $2 \times 2$ factorial design. This study was carried out in Agbani education zone of Enugu state. The population of the study comprised of four thousand, four hundred and eight $(4,408)$ senior secondary two (SSII) Biology students in Agbani Education Zone; consisting of two thousand, one hundred and fifteen $(1,815)$ males and two thousand, five hundred and ninety-three $(2,593)$ females (Post Primary School Education Board, Agbani, 2019/2020 session). The sample size for the study consisted of one hundred of eighty (150) SSII Biology students. The sample will be drawn using multistage sampling procedure. The instrument for data collection were Biology Achievement Test (BAT) and Biology Self-efficacy Scale (BSS). BAT was a 20-item multiple choice question with 4 options lettered A, B, C, D, which was scored 1 mark each, with a total of 20 marks. BAT was developed by the researcher which was drawn from the content scope. BSS was a likert scale instrument with 10 item questionnaire of response option strongly agree, agree, undecided, disagree and strongly disagree. The instruments were validated by three experts all from Department of Science Education, University of Nigeria, Nsukka. The reliability of BAT was determined using Kuder Richardson (K-R21) formula which gave a reliability index of 0.79 . The reliability of BSS gave an index of 0.81 using Cronbach alpha formula.

\subsection{Experimental Procedure}

The instruments for collection of relevant data (BAT and BSS) were administered to biology students in the sampled schools before the commencement of the experiment which serves as pretest score. This was done so as ascertain the initial knowledge of the students on biology curricular contents. The Biology teachers in the sampled school who served as research assistants where trained so as to help carry out with teaching. This was done so as to control the error that might arise as a result of teacher difference (ie. teacher variable) on students' achievement and self-efficacy in Biology, the regular Biology teachers in the sampled schools were trained and used for the study.

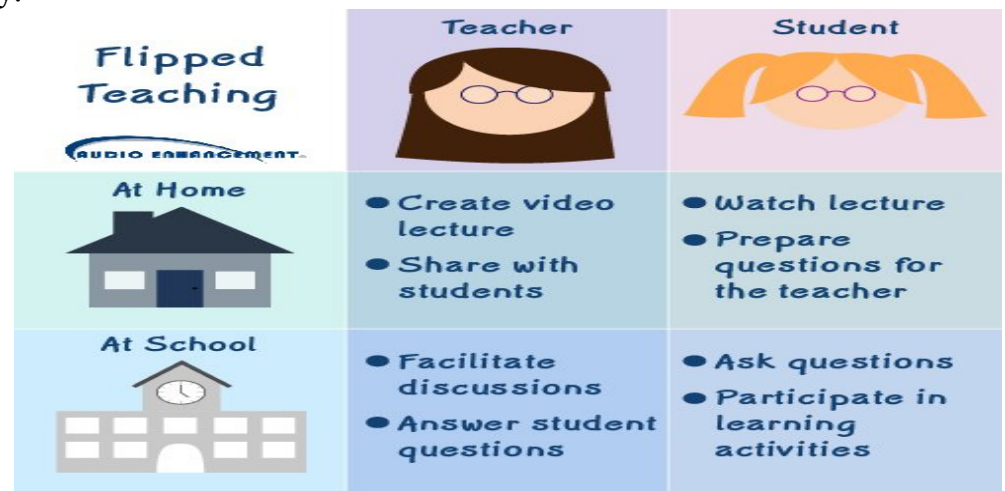

Figure 1: Steps tp invert your Classroom (Soruce: https://audioenhancement.com/) 


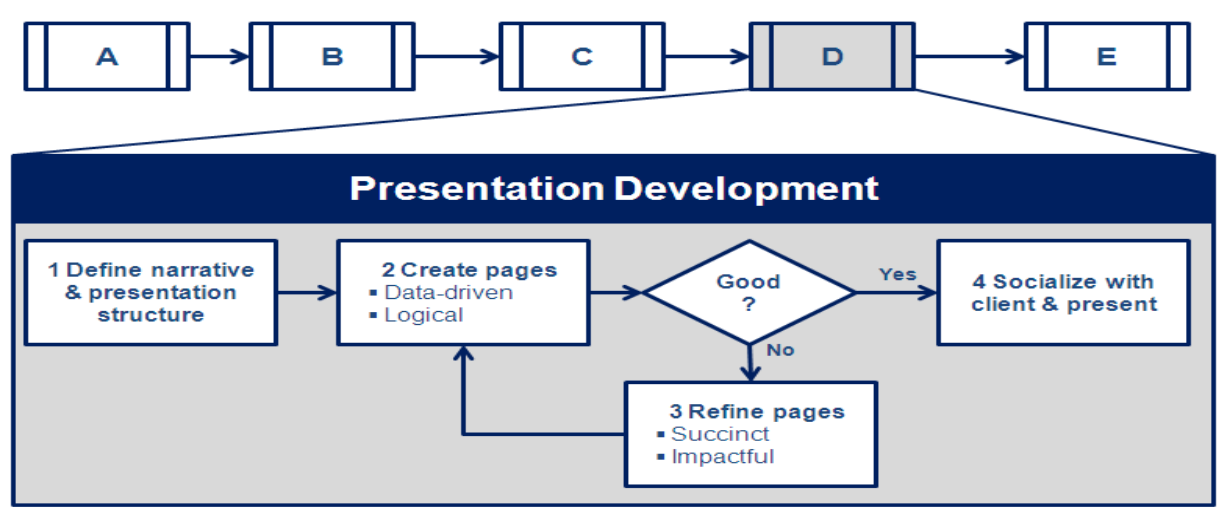

Figure 2: Steps to create PowerPoint (Source: https://www.consultantsmind.com/)

The training of the two Biology teachers took two days each, so as to master the treatment procedures. A copy of researcher's lesson plan developed by the researcher were made available to all the teachers to ensure uniformity. Thus, would control extraneous variable known as instruction situation variable. The experiment lasted for a total of five weeks. Thus, four weeks was used to teach the students, after which the BAT and BSS were administered in the fifth week as the post-test. Data obtained from the pre-test and post-test were quantitatively analysed. All the research questions were answered using mean and standard deviation while Analysis of Covariance (ANCOVA) were used to test all the hypotheses at 0.05 level of significance.

\section{Results}

Research Question One: What are the effect of inverted classroom approach and PowerPoint presentation on students' achievement in Biology?

Table 1: Pretest and Post-test Mean Achievement Score of Students Taught Biology using Inverted Classroom Approach and PowerPoint Presentation

\begin{tabular}{lcccccc}
\hline & \multicolumn{4}{c}{ Pre-test } & \multicolumn{2}{c}{ Post-test } \\
Group & N & Mean & SD & Mean & SD & Mean Difference \\
Inverted Classroom Approach (ICA) & 75 & 64.67 & 18.460 & 79.33 & 12.637 & 14.66 \\
PowerPoint Presentation (PPP) & 75 & 50.53 & 16.656 & 66.73 & 16.409 & 16.20 \\
\hline
\end{tabular}

NB: $x=$ Mean; $\mathrm{SD}=$ Standard Deviation

Result on Table 1 shows the pre-test and post-test mean achievement scores of students taught biology using inverted classroom approach and those taught using PowerPoint presentation. Result shows that the students taught biology using inverted classroom approach had mean achievement score of $(\bar{x}=64.67, \mathrm{SD}=$ $18.460)$ at the pre-test and mean achievement score of $(\bar{x}=50.53, \mathrm{SD}=16.656)$ at the post-test, while those who were taught biology using PowerPoint presentation had mean achievement score of $(\bar{x}=79.33, \mathrm{SD}=$ $12.637)$ at pre-test and mean achievement score of $(\bar{x}=66.73, \mathrm{SD}=16.409)$ at post-test. Mean difference of 14.66 and 16.20 for those taught biology using inverted classroom approach and those taught using PowerPoint presentation respectively imply that students taught biology using PowerPoint presentation performed better than those who were taught biology using inverted classroom approach. This implies that teaching biology using PowerPoint presentation proved to be more effective on students' achievement.

Hypothesis One: There is no significant effect of inverted classroom approach and PowerPoint presentation on students' achievement in biology

Table 2: Analysis of Covariance (ANCOVA) of the Difference in the Mean Achievement Score of Students taught Taught Biology using Inverted Classroom Approach and PowerPoint Presentation

\begin{tabular}{lccccccc}
\hline Source & $\begin{array}{c}\text { Type III Sum of } \\
\text { Squares }\end{array}$ & df & Mean Square & $\mathbf{F}$ & Sig. & $\boldsymbol{\eta}^{2} \mathbf{p}$ & Decision \\
Corrected Model & $17963.178^{\mathrm{a}}$ & 2 & 8981.589 & 66.912 & .000 & .477 \\
Intercept & 23916.272 & 1 & 23916.272 & 178.175 & .000 & .548 \\
Pre-test Ach & 12009.678 & 1 & 12009.678 & 89.472 & .000 & .378 & \\
Groups & 925.202 & 1 & 925.202 & 6.893 & .010 & .045 & $\mathrm{~S}$ \\
Error & 19731.655 & 147 & 134.229 & & & & \\
Total & 837775.000 & 150 & & & & & \\
Corrected Total & 37694.833 & 149 & & & & & \\
\hline
\end{tabular}

a. R Squared $=.477$ (Adjusted R Squared $=.469)$

NB: $S=$ Significant, NS = Not Significant, Sig. $=$ Significant and $\eta_{\mathrm{p}}^{2}=$ partial eta squared 
The result on Table 2 shows ANCOVA analysis of the significant effect of approaches on students' achievement in biology. The result shows that an f-ratio of $\left(F(1,149)=134.229, p<.05, \eta^{2}=.045\right)$ was obtained. Since the associated probability value of 0.010 is less than 0.05 set as level of significance, the null hypothesis which states that there is no significant effect of approaches on students' achievement in biology is rejected. Thus, inference drawn is that there is a significant effect of approaches on the achievement of students taught biology using inverted classroom approach, and those taught using the PowerPoint presentation with students taught using PowerPoint presentation having a higher mean in the post-test and a higher mean gain. This also implies that teaching biology using PowerPoint presentation proved to be more effective. The result further showed the effect size of $\left(\eta_{p}^{2}=0.045\right)$, which indicates that 4 percent variance in students' achievement in biology can be explained by the instructional approaches.

\section{Research Question Two:}

What are the effect of inverted classroom approach and PowerPoint presentation on students' self-efficacy in Biology?

Table 3: Pretest and Post-test Mean Self-efficacy Scale of Students Taught Biology using Inverted Classroom Approach and PowerPoint Presentation

\begin{tabular}{lcccccc}
\hline & \multicolumn{4}{c}{ Pre-test } & \multicolumn{2}{c}{ post-test } \\
Group & N & Mean & SD & Mean & SD & Mean Difference \\
Inverted Classroom Approach (ICA) & 75 & 38.47 & 12.627 & 53.00 & 16.045 & 14.53 \\
PowerPoint Presentation (PPP) & 75 & 42.53 & 12.202 & 65.60 & 14.611 & 23.07 \\
\hline
\end{tabular}

NB: $x=$ Mean; $\mathrm{SD}=$ Standard Deviation

Result in table 3 shows that students who were taught biology using inverted classroom approach had mean achievement score of $(\bar{x}=38.47, \mathrm{SD}=12.627)$ at the pretest and mean achievement score of $(\bar{x}=53.00, \mathrm{SD}=$ $16.045)$ at the posttest, while those who were taught biology using PowerPoint presentation had mean achievement score of $(\bar{x}=42.53, \mathrm{SD}=12.202)$ at pretest and mean achievement score of $(\bar{x}=65.60, \mathrm{SD}=$ 14.611) at posttest. Mean difference of 14.53 and 23.07 for those taught biology using inverted classroom approach and those taught using PowerPoint presentation respectively imply that students taught biology using PowerPoint presentation showed high self-efficacy than those taught using inverted classroom approach. This implies that teaching biology using PowerPoint presentation enhanced students' self-efficacy more than inverted classroom approach.

Hypothesis Two: There is no significant effect of inverted classroom approach and PowerPoint presentation on students' self-efficacy in biology

Table 4: Analysis of Covariance (ANCOVA) of the Difference in the Mean Self-efficacy ratings of Students taught Taught Biology using Inverted Classroom Approach and PowerPoint Presentation

\begin{tabular}{|c|c|c|c|c|c|c|c|}
\hline Source & $\begin{array}{l}\text { Type III Sum of } \\
\text { Squares }\end{array}$ & Df & $\begin{array}{l}\text { Mean } \\
\text { Square }\end{array}$ & $\mathbf{F}$ & Sig. & $\eta^{2} p$ & Decision \\
\hline Corrected Model & $16730.121^{\mathrm{a}}$ & 2 & 8365.061 & 51.084 & .000 & .410 & \\
\hline Intercept & 12604.979 & 1 & 12604.979 & 76.977 & .000 & .344 & \\
\hline Pre-test Self & 10776.621 & 1 & 10776.621 & 65.811 & .000 & .309 & \\
\hline Group & 3509.940 & 1 & 3509.940 & 21.435 & .000 & .127 & S \\
\hline Error & 24071.379 & 147 & 163.751 & & & & \\
\hline Total & 568275.000 & 150 & & & & & \\
\hline Corrected Total & 40801.500 & 149 & & & & & \\
\hline
\end{tabular}

a. $\mathrm{R}$ Squared $=.410$ (Adjusted R Squared $=.402)$

NB: $S=$ Significant, NS = Not Significant, Sig. = Significant and $\eta^{2}$ p = partial eta squared

The result on Table 4 shows ANCOVA analysis of the significant effect of approaches on students' selfefficacy in biology. The result shows that an f-ratio of $\left(F(1,149)=21.435, p<.05, \eta_{\mathrm{p}}^{2}=.127\right)$ was obtained. Since the associated probability value of 0.00 is less than 0.05 set as level of significance, the null hypothesis was rejected. Thus, it is concluded that there is a significant effect of approaches on the self-efficacy scores of students' taught biology using inverted classroom approach and those taught using the PowerPoint presentation with students taught using PowerPoint presentation having a higher mean in the post-test and a higher mean gain. This indicates that teaching biology using PowerPoint presentation proved to be more effective in enhancing students' self-efficacy. The result further showed the effect size of $\left(\eta_{p}^{2}=.127\right)$, which indicates that 12.7 percent variance in students' self-efficacy in biology can be explained by the instructional approaches.

\section{Discussion}

The findings of this study showed that teaching biology using PowerPoint presentation proved to be more effective on students' achievement than using inverted classroom approach. The result of this study could be due 
to the benefits of PowerPoint presentation as indicated by its underlining features which includes use of interesting multimedia presentations, use of narration and relevant images, and many more on students' achievement in biology. Than inverted classroom approach that deals with computers, smart gadgets, internet and many more which were not accessible to many students. Additional analysis revealed that there is a significant effect of approaches on the achievement of students taught biology using inverted classroom approach, and those taught using the PowerPoint presentation. The finding of this study is in-line with that of Adebanjo and Onabanjo (2021) whose study revealed that lecture method supplemented with PowerPoint presentation had significant effect on students' achievement in biology. Also, the finding of this study is in affirmation with other previous studies which showed the superiority of PowerPoint presentation on students' academic achievement in different science subjects. Such studies include those of Amosa, Hamdalat and Sherifat (2020), Ugwuanyi, Nwankwo \& Ugwuoke (2016), Sewasew, Mengestie and Abate (2015), Ebuoh \& Ebuoh (2014), Hasan, Mustafa, Mehmet, Ali and Kahraman (2013). On the contrary, the finding of this study is not in consonance with those of Ugwuanyi, Nduji, Elejere and Omeke (2020), Karadag and Keskin (2017), Malto, Dalida and Lagunzad (2017) whose studies respectively unveiled that flipped learning approach positively affect students' academic achievement toward science subjects like mathematics and physics lessons. This finding indicates that the use of flipped classroom alone can lead to an improved students' achievement.

The report from the finding of this study also showcased that teaching biology using PowerPoint presentation enhanced students' self-efficacy more than inverted classroom approach. Besides it was also revealed on further analysis that there is a significant effect of approaches on the self-efficacy scores of students' taught biology using inverted classroom approach and those taught using the PowerPoint presentation in favour of students taught using PowerPoint presentation. This result is in affirmation with the finding of Susskind (2015) whose report showed that students had more positive attitudes about the course and greater self-efficacy with PowerPoint. Marina and Ridlo (2020) study is in agreement since the finding revealed that flipped classroom is effective to improve students' understanding of concepts and self-efficacy in circulatory system materials. AlJaser (2017) reported a positive correlation between the students' post achievement test and their attitudes towards self-efficacy scale; indicating that the more scores the students get in achievement test, the more selfefficacy they have. The finding of AlJaser (2017) is in alignment with the present study. In addition, the result of this study is in alignment with those of Zdaniuk, Gruman, \& Cassidy (2019), Zafarghandi, (2018), and Cravero (2017) whose studies investigated the effect of flipped learning method on students' achievement, gender and self-efficacy reported that mean scores of academic achievement and self-efficacy of students who received the flip learning method were significantly higher than the average grades of students who used the traditional method.

\section{Conclusion}

Based on the findings from this study, the researcher drew the conclusion, thus; students taught biology using PowerPoint presentation showed superiority in their achievement and self-efficacy than their counterparts who were taught biology using inverted classroom approach.

\section{Recommendation}

The following recommendations have been made based on the findings from this study:

1. Biology teachers should try to develop and adopt the use of PowerPoint presentation in their instructional delivery as it would enhance overall achievement and self-efficacy of students in biology.

2. Regular sensitisation workshops should be organised to retrain biology teachers on the development and use of technologically driven learning approaches.

3. The use of PowerPoint presentation approach should be encouraged during pre-service teacher training programs.

\section{References}

Adebanjo, A. \& Onabanjo, O. (2021). Effect of lecture method supplemented with powerpoint presentation on students' academic achievement in Biology. Retrieved 2 $2^{\text {nd }}$ July, 2021, from https://www.semanticscholar.org/paper/Effects-of-Lecture-Method-Supplemented-with-on-

Akachukwu, E.E., Adimonyemma, N.R. \& Igboabuchi, N.A. (2018). Influence of parents' socio-economic status on the academic achievement in Biology of public senior secondary school students in Orlu LGA Imo State. British Journal of Education, Learning and Development Psychology, 1(1), 66-73.

Albert, O.O., Osman, A. \& Yungungu, A. (2016). An investigation of Factors that Influence Performance in KCSE Biology in selected secondary schools in Nyakach District, Kisumu County, Kenya. Journal of Education and Human Development, 3(2), 957-977.

AlJaser, A.M. (2017). Effectiveness of using flipped classroom strategy in academic achievement and selfefficacy among education students of Princess Nourah bint Abdulrahman University. English Language 
Teaching, 10(4). http://doi.org/10.5539/elt.v10n4p67

Amosa, I.G., Hamdalat, T.Y. \& Sherifat, A.B. (2020). Effectiveness of powerpoint presentation on students' cognitive achievement in technical drawing. Malaysian Online Journal of Educational Technology, 3(4), $112-125$

Anigbo, L.C. \& Orie, M.J. (2018). Effect of powerpoint instruction on students' academic achievement in Computer Science (Database Management System) in colleges of education in Rivers State. Computer Engineering and Intelligent Systems, 9(1), 1-6.

Badmus, S.T., Bello, G., Hamzat, A. \& Sulaiman, M.M. (2019). Effects of webquest on secondary school Biology students' achievement in cell division in Ilorin. Humanities and Social Sciences Letters, 7(2), 6473.

Bandura, A. (2010). Self-efficacy. The Corsini Encyclopedia of Psychology, American Cancer Society, 1-3.

Buba, A.M., Banus, A.A. \& Adamu, M. (2020). Gender differences in effectiveness of constructivist method of teaching Biology on academic performance of senior secondary school students in Maduguri metropolis, Borno state, Nigeria. African Journal of Science Technology and Mathematics Education, 5(1), 41-47.

Cravero, S.E.C. (2017). The effects of provided powerpoint presentations on student perceptions of personal responsbility. A PhD Thesis, Western Kentucky University, Bowling Green, KY 42101, USA.

Ebuoh, C.N. \& Ebuoh, M.M. (2014). Effects of slides and filmstrips on students' achievements in Biology in secondary schools. Journal of Teacher Perspective, 8(3), 173-185.

Etobro, A.B. \& Fabinu, O.E. (2017). Students' perceptions of difficult concepts in Biology in senior secondary schools in Lagos State. Global Journal of Educational Research, 16, 139-147. http://dx.doi.org/10.4314/gjedr.v16i2.8

Fernando, D., Laura, A. \& Amparo, G. (2017). Self-efficacy, satisfaction, and academic achievement: the mediator role of students' expectancy-value beliefs. Frontiers in Psychology, 18(3), https://doi.org/10.3389/fpsyg.2017.01193

Gill, E. (2021). What is your teaching style? 5 effective teaching methods for your classroom. Retrieved from https://resilienteducator.com/classroom-resources/5-types-of-classroom-teaching-styles/

Hasan, G., Mustafa, K., Mehmet, E., Ali, A., \& Kahraman, S. (2010). The effect of PowerPoint presentations prepared and presented by prospective teachers on biology achievement and attitudes toward biology. Procedia Social and Behavioral Sciences, 2, 3043-3047.

https://audioenhancement.com/flipped-teaching-what-is-it/

https://www.consultantsmind.com/2012/12/05/consultant-powerpoint/

Ihekwoaba, C.C. (2020). Improving students' achievement and interest in biology: The use of peer tutoring. (An Unpublished M.Ed Project), University of Nigeria Nsukka, Enugu state, Nigeria.

Ihekwoaba, C.C., Nzewi, U.M., Ifeagwu, N.A. (Sr), Chinweuba-eze, V.O. \& Nduji, C.C. (2020). Improving students' achievement in Biology: The use of peer tutoring. European Journal of Training and Development Studies, 7(5), 1-15

Jakobsen, K.V. \& Knetemann, M. (2017). Putting structure to flipped classrooms using team-based learning. International Journal of Teaching and Learning in Higher Education, 29(1), 177-185.

Karadag, R. \& Keskin, S. (2017). The effects of flipped learning approach on the academic achievement and attitudes of the students. New Trends and Issues Proceedings on Humanities and Social Sciences, 4(6),158168. https://doi.org/10.18844/prosoc.v4i6.2926

Lari, F.S. (2014). The impact of using PowerPoint presentations on students' learning. Procedia - Social and Behavioral Sciences, 98, 1672 - 1677.

Malto, G.A., Dalida, C.S. \& Lagunzad, C.G.B. (2017). Flipped classroom approach in teaching Biology: Assessing students' academic achievement and attitude towards Biology. Retreieved $21^{\text {st }}$ June, 2021, from https://knepublishing.com/index.php/KnE-Social/article/view/2403/5284

Mansour, F.S.O. (2019). The impact of using powerpoint presentations on students' achievement and information retention in teaching English language at public schools in Amman. Retrieved June 19 ${ }^{\text {th }}, 2021$, from https://meu.edu.jo/libraryTheses/5d36a8f8abe9a_1.pdf

Marina, H. \& Ridlo, S. (2020). The effectiveness of flipped classroom to improve students' concept understanding and self efficacy during the covid-19 pandemic. Journal of Biology Education, 10(1), 215231. https://doi.org/10.15294/jbe.v10i1.4519

Ndayambaje, J.B., Bikorimana' E. \& Nsanganwimana, F. (2021). Factors contributing to the students' poor performance in Biology subject: A case study of ordinary level in rural secondary schools of Rwamagana district. GSC Biological and Pharmaceutical Sciences, 15(3), $249-261$. https://doi.org/10.30574/gscbps.2021.15.3.0163

Onu, W.O., Anyaegbunam, N.J. \& Uzoigwe, A.U. (2020). Improving Biology Students' Interest and Achievement through Collaborative Instructional Strategy. Journal of Education, Society and Behavioural Science, 33(2), 9-20. 
Penciner, R. (2013). Does PowerPoint enhance learning? CJEM: Journal of the Canadian Association of Emergency Physicians, 15(2), 109-12.

Rankin, E.L. \& Grudzinki, M. (2011). The use of powerpoint and students performance. Atlantic Economic Journal, 29, 133-127.

Robinson, S.P., Roland, G., Bosse, C. \& Zayas, E. (2015). Effectiveness of flipped classroom technique in an advanced laboratory Physics course. Proceedings of the Conference on Laboratory Instruction BFY, 92-95.

Sarah, B. (2015). Flipped classroom vs flipped learning. What is the difference? Retrieved $15^{\text {th }}$ July, 2021, from https://blog.capterra.com/flipped-classroom-vs-flipped-learning-whats-the-difference/

Schindler, L.A., Burkholder, G.J., Morad, O.A. (2017). Computer-based technology and student engagement: A critical review of the literature. Int J Educ Technol High Educ, 14(25). https://doi.org/10.1186/s41239-0170063-0

Sewasew, D., Mengestie, M. \& Abate, G. (2015). A comparative study on powerpoint presentation and traditional lecture method in material understandability, effectiveness and attitude. Educational Research and Review, 10(2), 234-243

Sotiloye, B. \& Bodunde, H. (2018). Assessment of students' reading culture in a Nigerian university: Waxing or waning? Legon Journal of the Humanities, 29(2), 285-307. https://dx.doi.org/10.4314/1jh.v29i2.11

Susskind, J.E. (2015). PowerPoint's power in the classroom: Enhancing students' self-efficacy and attitudes. Computers \& Education, 45(2), 203-215. https://doi.org/10.1016/j.compedu.2004.07.005

Tolks, D., Schäfer, C., Raupach,T., Kruse, L., Sarikas, A., Gerhardt-Szép, S., Kllauer, G., Lemos, M., Fischer, M.R., Eichner, B., Sostmann, K. \& Hege, I. (2016). An introducation to the inverted flipped/ classroom in education and advance training in medicaing and healthcare professions. GMS Journal of Medical Education, 33(3), https://doi.org/10.3205/zma001045

Triantoro, S. (2013). Effects of Self-Efficacy on Students' Academic Performance. Journal of Educational Health and Community Psychology, 2(1), 19-25

Ugwuanyi, C.S., Nduji, C.C., Elejere, U.C. \& Omeke, N.E. (2020). Effect of flipped classroom and think pair share strategy on achievement and retention among senior secondary school Physics students. International Journal of Sciences: Basic and Applied Research (IJSBAR), 52(2), 136-148.

Ugwuanyi, C.S., Nduji, C.C., Gana, C.S., Nwajiuba, C.A., Ene, C.U., Okeke, A.O., Eseadi, C. \& Okeke, C.S. (2020). Effectiveness of flipped classroom instructional technology model in enhancing students' achievement in Physics. International Journal of $u$ - and e-Service, Science and Technology, 12(4), 37-46.

Ugwuanyi, C.S., Nwankwo, C. \& Ugwuoke, E. (2016). Assessment of the efficacies of powerpoint presentation and demonstration methods on the interest and achievement of students in Physics. Science Teachers Association of Nigeria $57^{\text {th }}$ Annual Conference Proceedings, 487-493.

Zafarghandi, M. (2018). The effect of flip learning on students' self-efficacy and academic achievement. Retrieved $21^{\text {st }}$ July, 2021, from https://papers.ssrn.com/sol3/papers.cfm?abstract_id=3154001

Zawadi, L. (2020). Types of teaching methods, their advantages and disadvantages. Retrieved $11^{\text {th }}$ July, 2021, from https://www.legit.ng/1143440-types-teaching-methods-advantages-disadvantages.html

Zdaniuk, A., Gruman, J.A. \& Cassidy, S.A. (2019). PowerPoint slide provision and student performance: the moderating roles of self-efficacy and gender. Journal of Further and Higher Education, 43(4), 467-481. https://doi.org/10.1080/0309877X.2017.1367369

Zhang, J., Yen, S.H. \& Liu, T.C. (2020). Studies on learning effects of ar-assisted and PPT-based lectures. AsiaPacific Edu Res. 6(3). https://doi.org/10.1007/s40299-020-00533-x 